\title{
Phytoavailability of Zinc in Postbloom Zinc Sprays Applied to 'Golden Delicious' Apple Trees
}

\author{
Frank J. Peryea ${ }^{1}$
}

ADDITIONAL INDEX WORDs. Malus $\times$ domestica, tree fruit, mineral nutrition, foliar spray, micronutrient

Summary. Postbloom zinc $(\mathrm{Zn})$ sprays are replacing dormant and postharvest sprays as the primary means for applying $\mathrm{Zn}$ in commercial apple (Malus $\times$ domestica) orchards. We conducted a multiyear field study comparing the phytoavailability of $\mathrm{Zn}$ in 11 commercially available $\mathrm{Zn}$ spray products, plus reagent-grade $\mathrm{Zn}$ nitrate and a water-sprayed control, applied postbloom at identical $\mathrm{Zn}$ concentrations to 'Golden Delicious' apple trees. Two sprays were applied per season (mid-May and mid-June), at per-spray rates of either $0.5 \mathrm{lb} /$ acre in 2000 or 1.0 $1 b / a c r e$ in 2001 and 2002. No sprays were applied in 2003 in order to evaluate carry-over effects. The $\mathrm{Zn}$ sprays had no effect on fruit number, bitter pit or russeting, or on leaf green color. Zinc concentrations of detergent plus acidwashed leaves (a procedure used to remove surface residues of the $\mathrm{Zn}$ sprays) sampled in August and of unwashed winter buds sampled the following January were used as indices of tree $\mathrm{Zn}$ status. Leaf $\mathrm{Zn}$ concentration generally increased in the order: $\mathrm{Zn}$ phosphate $<\mathrm{Zn}$ oxide $=\mathrm{Zn}$ oxysulfate $<$ chelated $/$ organically complexed $\mathrm{Zn}_{\mathbf{n}} \leq \mathrm{Z}_{\mathbf{n}}$ nitrate. There was little consistent difference among chelated and organically complexed $\mathrm{Zn}$ products. Leaf $\mathrm{Zn}$ concentration varied considerably between seasons, and was not related to $\mathrm{Zn}$ application rate. All of the $\mathrm{Zn}$ sprays increased leaf $\mathrm{Zn}$ concentrations to desirable levels. Because the inorganic $\mathrm{Zn}$-based products typically are substantially less expensive per unit of $\mathbf{Z n}$, it may be less costly and just as effective to use a higher rate of an inorganic $\mathrm{Zn}$ product as to use a lower rate of a more expensive chelated or organically complexed $\mathrm{Zn}$ product. On the other hand, use of low rates of highly phytoavailable $\mathrm{Zn}$ products minimizes release of the nutritionally essential but potentially ecohazardous metal into the environment. There was no detectable lasting effect of the three previous seasons of $\mathrm{Zn}$ sprays on leaf $\mathrm{Zn}$ in 2003. Similarly, there was no detectable effect in any year of the $\mathrm{Zn}$ spray treatments on bud $\mathrm{Zn}$ concentration the following winter. These results suggest that the amount of $\mathrm{Zn}$ supplied by the sprays at the tested rates was insufficient to promote substantial $\mathrm{Zn}$ accumulation within the trees, thereby validating the recommendation for annual application of $\mathrm{Zn}$ nutritional maintenance sprays.

$\mathrm{Z}$ inc deficiency is widespread in apple orchards in the western United States and British Columbia (Luce and Bartram, 1947; Neilsen, 1988; Oberly and Boynton, 1966). It occurs naturally and visually is expressed as little leaf, rosetting, leaf chlorosis, blind wood, and shoot dieback (Woodbridge, 1954). Zinc deficiency can reduce the amount of marketable fruit in affected orchards because of its direct influence on the

${ }^{1}$ Research Soil Scientist and Horticulturist, Tree Fruit Research and Extension Center, Washington State University, 1100 North Western Avenue, Wenatchee, WA 98801

This research was conducted under Project WNP0747, College of Agricultural, Human, and Natural Resource Sciences, Washington State University, Pullman. Funding support was provided by the College and by the Washington Tree Fruit Research Commission.

I thank Jennifer Moore and Casimir Lorentz for their technical support. amount of viable fruiting wood. Dormant sprays of high rates of inorganic Zn salts traditionally used on apple trees usually eliminated $Z n$ deficiency symptoms but often were found to have little or no effect on leaf $\mathrm{Zn}$ concentration (Benson, 1953a; Heeney et al., 1964; Neilsen and Hoyt, 1990). Postharvest Zn sprays sometimes were less effective than dormant sprays for controlling
$\mathrm{Zn}$ deficiency symptoms on apple, and have been associated with delayed dormancy and possible winter injury (Benson, 1953a; Lindner and Luce, 1944; Neilsen and Hoyt, 1990).

Because of their greater effect on leaf $\mathrm{Zn}$ concentration, postbloom sprays of $\mathrm{Zn}$ applied at lower rates and as safer formulations are replacing dormant and postharvest $\mathrm{Zn}$ sprays (Hoffman and Samish, 1966; Neilsen and Hogue, 1983; Orphanos, 1975; Sanchez and Righetti, 2002; Swietlik, 2002). Movement of foliarly applied radiolabeled or heavy isotopic $\mathrm{Zn}$ into fruit and nut tree leaves and subsequent intra-plant transport of the absorbed $\mathrm{Zn}$ have been confirmed (Boaretto et al., 2002; Crowley et al., 1996; Wadsworth, 1970; Zhang and Brown, 1999a, 1999b). There are many commercially available $\mathrm{Zn}$ nutritional spray products labeled for postbloom use, which vary in $\mathrm{Zn}$ concentration, physical state, chemical composition, and cost. The chemistry of these sprays directly influences their effectiveness (Ferrandon and Chamel, 1988). Postbloom Zn sprays under some conditions can impair fruit finish, particularly the incidence and severity of russeting (Benson, 1953b). In addition to improving apple tree $\mathrm{Zn}$ nutrition, adopting spray practices and products that enhance fertilizer $\mathrm{Zn}$ phytoavailability can lower $\mathrm{Zn}$ application rates, thereby reducing environmental loading with this potentially ecohazardous heavy metal (Peryea, 2001).

Use of postbloom sprays complicates interpretation of leaf $\mathrm{Zn}$ analysis by creating a possibility of leaf surface contamination. Numerous researchers have addressed this issue by evaluating or recommending a sequential detergent and hydrochloric acid $(\mathrm{HCl})$ washing procedure to remove surface $\mathrm{Zn}$ spray residues. Adding an acid wash step to the normal detergent washing procedure usually but not always removed an additional amount of $\mathrm{Zn}$

\begin{tabular}{llll}
\hline $\begin{array}{l}\text { Units } \\
\begin{array}{l}\text { To convert U.S. to SI, } \\
\text { multiply by }\end{array}\end{array}$ & U.S. unit & SI unit & $\begin{array}{l}\text { To convert SI to U.S., } \\
\text { multiply by }\end{array}$ \\
\hline 10 & $\%$ & $\mathrm{~g} \cdot \mathrm{kg}^{-1}$ & 0.1 \\
0.4047 & $\mathrm{acre}(\mathrm{s})$ & $\mathrm{ha}$ & 2.4711 \\
0.3048 & $\mathrm{ft}$ & $\mathrm{m}$ & 3.2808 \\
3.7854 & $\mathrm{gal}$ & $\mathrm{L}$ & 0.2642 \\
25.4000 & $\mathrm{inch}(\mathrm{es})$ & $\mathrm{mm}$ & 0.0394 \\
1.1209 & $\mathrm{lb} / \mathrm{acre}$ & $\mathrm{kg} \cdot \mathrm{ha}^{-1}$ & 0.8922 \\
28.3495 & $\mathrm{oz}$ & $\mathrm{g}$ & 0.0353 \\
1 & $\mathrm{ppm}$ & $\mathrm{mg} \cdot \mathrm{kg}^{-1}$ & 1 \\
$\left({ }^{\circ} \mathrm{F}-32\right) \div 1.8$ & ${ }^{\circ} \mathrm{F}$ & ${ }^{\circ} \mathrm{C}$ & $\left(1.8 \times{ }^{\circ} \mathrm{C}\right)+32$ \\
& & &
\end{tabular}


compared to detergent washing alone. Ashby (1969) and Smith and Storey $(1976,1979)$ felt that leaf $Z n$ remaining after detergent plus acid washing was located within the leaf tissue; however, most authors concluded that some external residues were likely to remain on or embedded in the detergent plus acid-washed leaf surfaces (Chamel et al., 1982; Labanauskas, 1966; Orphanos, 1975, 1977; Smith et al., 1950). Unwashed, detergent-washed, and detergent plus acid-washed leaves from unsprayed fruit trees exhibited identical Zn concentrations, suggesting that the washing procedure does not remove internal leaf $\mathrm{Zn}$ (Ashby, 1969; Crowley et al., 1996; Smith and Storey, 1976).

Movement of fertilizer $\mathrm{Zn}$ into tree leaves has been confirmed when the $\mathrm{Zn}$ is soil-applied (Sparks and Payne, 1982) or foliarly applied (Boaretto et al., 2002; Crowley et al., 1996; Zhang and Brown, 1999a, 1999b). The lastmentioned authors demonstrated that transport of absorbed $\mathrm{Zn}$ within and out of $\mathrm{Zn}$-treated leaves increased concurrently with a decline in leaf $\mathrm{Zn}$ recalcitrant to detergent plus acid washing, suggesting that, even if some of the $\mathrm{Zn}$ recalcitrant to detergent plus acid washing has not been absorbed, it may continue to be phytoavailable. This result was consistent with that of Boaretto et al. (2002), who showed that leaf $\mathrm{Zn}$ recalcitrant to detergent plus acid washing increased with residence time of radiolabeled $\mathrm{Zn}$ solution on the leaf surface, followed by movement of radiolabeled $\mathrm{Zn}$ into other portions of the plants not directly contacted by the $\mathrm{Zn}$ solution.

Given these circumstances, it will be difficult to ascertain that the $\mathrm{Zn}$ concentration measured in detergent plus acid-washed leaves does not overestimate the concentration of metabolically active $\mathrm{Zn}$ in $\mathrm{Zn}$-sprayed leaves; however, it should provide a more accurate estimate than does $\mathrm{Zn}$ analysis of unwashed or detergentonly-washed leaves. Zinc concentration in detergent plus acid-washed leaves was used to diagnose $\mathrm{Zn}$ nutritional requirements (Herrera, 2000; Smith and Storey, 1976) or to quantify the relative effects of $\mathrm{Zn}$ spray products or spray adjuvants on leaf $\mathrm{Zn}$ status (Boaretto et al., 2002; Crowley et al., 1996; Hoffman and Samish, 1966; Labanauskas and Puffer, 1964; Orphanos, 1975, 1977, 1982; Smith and Storey, 1979).

The current study was conducted to evaluate the relative phytoavailability and some secondary effects of commercially available $\mathrm{Zn}$ spray products applied postbloom to apple trees grown under field conditions. The detergent plus acid washing procedure was used to operationally partition leaf $\mathrm{Zn}$ between potentially phytoactive and inert surface residue pools.

\section{Materials and methods}

The study was conducted in an irrigated 'Golden Delicious' / Malling 9' apple orchard planted in 1985 in Wenatchee, Wash. The natural environment is semi-arid sagebrush-steppe. Annual precipitation averages $265 \mathrm{~mm}$. Average January and July temperatures are -1.7 and $22{ }^{\circ} \mathrm{C}$, respectively. The soil is classified as a Burch loam, a coarse-loamy, mixed, superactive, mesic Aridic Haploxeroll. The trees were planted at a $4 \times 12$ - $\mathrm{ft}$ spacing $(907.5$ trees/acre) and were supported by a metal conduit-wire trellis system. The trees were irrigated using a permanent undertree high pressure/high volume sprinkler system. Herbicides were used to maintain a weed-free strip within tree rows. Chemical and hand-thinning of fruit, and control of insect and disease pests were carried out using commercial practice (Smith, 2000).

Thirty-nine experimental plots of single 'Golden Delicious' apple trees were identified in four adjacent tree rows. Plots are physically separated within-row by five guard-trees, while experimental trees in adjacent rows are offset by three guard-trees. Thirteen spray treatments, including water, reagent-grade $\mathrm{Zn}$ nitrate, and $11 \mathrm{com}-$ mercially available $\mathrm{Zn}$ spray products of varying composition, were imposed on the 39 plots using a randomized complete-block design with three replications (Table 1). Zinc sulfate and $\mathrm{Zn}$ chloride were not included in the study. While they are highly soluble in aqueous solution, both have been shown to cause fruit phytotoxicity and therefore are not used commercially on bearing trees postbloom (Benson, 1953a; Boaretto et al., 2002). Solutions or suspensions of the 12 $\mathrm{Zn}$-containing spray products were prepared in polyethylene containers, with individual containers prepared for each experimental plot. Each container contained a constant quantity of actual $\mathrm{Zn}(0.25 \mathrm{~g}$ in 2000 and $0.5 \mathrm{~g}$ in 2001 and 2002) and 1.2 L tap water (average amount established empirically on guard trees as that required to bring the single tree of each experimental plot to drip). The entire content of each container was applied to each plot

Table 1. Zinc products used to compare tree responses to and zinc phytoavailability from postbloom zinc sprays applied to 'Golden Delicious' apple trees.

\begin{tabular}{lccll}
\hline Product name & $\begin{array}{c}\text { Physical } \\
\text { state }\end{array}$ & $\begin{array}{c}\text { Zinc content } \\
(\mathbf{\%} \text { by } \mathbf{~ w t})\end{array}$ & $\begin{array}{c}\text { Principal ligand } \\
\text { accompanying zinc }\end{array}$ & \multicolumn{1}{c}{ Manufacturer } \\
\hline Zinc nitrate & solid & 22.0 & nitrate & J.T. Baker, Phillipsburg, N.J. \\
Nutra-Phos 0-24-0 & solid & 12.0 & Phosphate & Pace International, Seattle, Wash. \\
Nutra-Phos Zn-K & solid & 31.0 & Phosphate & Pace International \\
Tech-Flo Zeta Zinc 22 & liquid & 10.0 & oxysulfate & Putrient Technologies, La Habra, Calif. \\
Nutra-Spray Zn & solid & 50.0 & sulfate, oxide & Pace International \\
Keylate Zinc & liquid & 9.0 & carboxylate & Stoller Enterprises, Houston, Texas \\
Zinc Polyamine & liquid & 5.8 & glucosamine & PhytoChem Laboratories, Pasco, Wash. \\
ZincMax & liquid & 10.2 & carbohydrate & NutriAg, Toronto, Ontario \\
Biomin Zinc & liquid & 7.0 & glycine & JH Biotech, Ventura, Calif. \\
Zinc X-tra & liquid & 10.0 & fulvic acid & Custom Agricultural Formulations, Fresno, Calif. \\
CM Liquid 9\% Zinc & liquid & 9.0 & lignosulfonate & Custom Agricultural Formulations \\
Metalosate Zinc & liquid & 6.8 & amino acids & Albion Advanced Nutrition, Clearfield, Utah \\
\hline
\end{tabular}

${ }^{2}$ Some products contain additional minor components. 
using a portable hand-pump sprayer. The nominal $\mathrm{Zn}$ rate was $0.5 \mathrm{lb} /$ acre per spray in 2000 and $1.0 \mathrm{lb} /$ acre per spray in 2001 and 2002, applied twice per season. The first spray was applied in mid-May about 1 week after petalfall, and the second about 4 weeks later. No sprays were applied in 2003 to evaluate possible carry-over effects of the sprays applied during the previous three seasons.

In addition to the experimental treatments, all of the trees received a foliar spray of $0.55 \mathrm{lb} /$ acre boron (B) in late May 2000. In 2001, they received foliar sprays of $0.55 \mathrm{lb} /$ acre $\mathrm{B}$ at delayed dormant, $4 \mathrm{lb} /$ acre nitrogen $(\mathrm{N})$ and $8.7 \mathrm{lb} /$ acre sulfur $(\mathrm{S})$ at petal-fall, and $1.5 \mathrm{lb} /$ acre per spray of calcium $(\mathrm{Ca})$ in the first through third cover sprays. In 2002, all of the trees received nutrient sprays of $0.25 \mathrm{lb} /$ acre $\mathrm{B}$ at delayed dormant, $4 \mathrm{lb} / \mathrm{acre} \mathrm{N}$ and $8.7 \mathrm{lb} /$ acre $S$ at petal-fall, $0.5 \mathrm{lb} /$ acre copper $(\mathrm{Cu})$ in the first cover spray, and $1.5 \mathrm{lb} /$ acre per spray of $\mathrm{Ca}$ in the second through fourth cover sprays. In 2003 , all of the trees received the $\mathrm{N}$, $S$, and Ca sprays at the 2002 rates and timings. The B sources were organically complexed boric acid or sodium $(\mathrm{Na})$ polyborate products. The source of $\mathrm{N}$ and $\mathrm{S}$ was foliar-grade ammonium thiosulfate. The Ca source was organically complexed Ca oxide.

Plant tissue analyses. In early Aug. 2000 and 2001, 20 leaf samples were sampled randomly from each experimental tree, selecting mid-shoot leaves on current season's growth. The leaf samples were split randomly into two subsamples of 10 leaves each. The first subsample leaves were oven-dried at $65^{\circ} \mathrm{C}$ without washing. The second subsample leaves were individually washed by hand using sequential $0.5 \%$ $(\mathrm{v} / \mathrm{v})$ detergent wash, tap water rinse, washing in $8 \mathrm{~L}$ of $0.1 \mathrm{M} \mathrm{HCl}$, flowing tap water rinse, and flowing deionized water rinse. Both the adaxial and abaxial leaf surfaces were gently rubbed by the operator's gloved fingers in the detergent and acid baths during the cleaning process. The acid solution was changed after every 10 samples to reduce likelihood of cross-contamination. This cleaning procedure is similar to that used for pecan (Carya illinoinensis) leaves by Smith and Storey (1976) except that Liquinox was used in place of Alconox (both Alconox, Inc., White Plains, N.Y.) to avoid phosphorus (P) contamination. The detergent plus acid-washed leaves then were ovendried at $65^{\circ} \mathrm{C}$. In 2002 and 2003,10 leaf samples were sampled randomly from each tree, subjected to the detergent plus acid washing procedure only, dried, and ground. In Jan. 2001-04, 10 buds were sampled randomly from each experimental tree and oven-dried at $65^{\circ} \mathrm{C}$ without washing.

All dried plant tissue samples were ground in a stainless steel Wiley mill and analyzed for $\mathrm{N}, \mathrm{P}$, potassium $(\mathrm{K}), \mathrm{Ca}$, magnesium $(\mathrm{Mg}), \mathrm{S}, \mathrm{Zn}, \mathrm{B}$, manganese $(\mathrm{Mn})$, iron $(\mathrm{Fe}), \mathrm{Cu}$, aluminum $(\mathrm{Al})$, and Na concentrations. Nitrogen was determined by total Kjeldahl digest and flow injection colorimetry, and the other mineral elements by wetdigestion, followed by assay using inductively coupled plasma-atomic emission spectroscopy. Plant tissue analytical data are reported on a dry weight basis.

FRUIT RESPONSES AND LEAF COLOR. The percentage of fruit with bitter pit was determined by visually inspecting every apple in each plot at commercial harvest in Sept. 2000 and 2002-03. A fruit was considered to have bitter pit if one lesion was present. The percentage of fruit that failed to meet the russeting standard for Washington Grade C or higher, “... the aggregate area of an apple which may be covered by smooth net-like russeting shall not exceed 25 percent; and the aggregate area of an apple which may be covered by smooth solid russeting shall not exceed 10 percent" (Washington State Legislature, 2003), was determined visually. The fruit response data for 2001 could not be calculated because of a data collection error. Leaf green color was measured nondestructively in late July $2001-04$ on 20 randomly selected leaves per plot using a SPAD502 chlorophyll meter (Minolta Camera Co., Osaka, Japan).

Statistical ANALYSES. Treatment response data were analyzed by year using analysis of variance. Mean separation was done using Duncan's multiple range test when the analysis of variance indicated a significant main treatment effect. Statistical analyses were carried out using SAS (release 8.0 TS Level 00M0 for Windows; SAS Institute, Cary, N.C.). Statistical significance was defined at $P \leq 0.05$.

\section{Results and discussion}

No Zn deficiency symptoms appeared on any of the experimental trees at any time. The $\mathrm{Zn}$ spray treatments had no effect on crop yield, bitter pit incidence, the percentage of fruit failing to meet the Washington Grade C or higher russeting standard, or leaf SPAD value (data not shown). Experiment-wide fruit responses varied between years. For the years 2000, 2002 , and 2003 , yield averaged 47.3 , 19.7 , and 94.5 fruit per tree; bitter pit incidence averaged $1.6 \%, 0.6 \%$, and $2.8 \%$; and russeting incidence averaged $15 \%, 78 \%$, and $47 \%$. The low fruit numbers in 2002 resulted from chemical overthinning. Interveinal and marginal chlorosis often appears on $\mathrm{Zn}$-deficient apple trees before other symptoms (Neilsen and Hoyt, 1990; Woodbridge, 1954). Chlorosis was absent in the current experiment. Leaf greenness, averaged across treatments, ranged from 43.5 to 46.4 SPAD units during the experiment. These values are consistent with those reported for 'Golden Delicious' / Malling 9' orchards in northern Italy (Porro et al., 2001). These results suggest that the $\mathrm{Zn}$ status of the experimental trees, although sometimes low (Fig. 1; Table 2) was sufficient to preclude $\mathrm{Zn}$ deficiency-related symptoms, and that $\mathrm{Zn}$ sprays could be safely applied postbloom at the tested rates.

All of the $\mathrm{Zn}$ sprays produced high $\mathrm{Zn}$ concentrations in the unwashed leaves, with $\mathrm{Zn}$ nitrate having the highest mean $\mathrm{Zn}$ concentration. Products containing sticky components or additives, such as Zeta Zinc 22 and Zinc-Max, tended to generate high unwashed Zn concentrations. Adjuvant stickers and surfactants can help reduce loss of sprayed $\mathrm{Zn}$ during application and subsequent weathering (Crowley et al., 1996). The detergent plus acid washing procedure substantially lowered the $\mathrm{Zn}$ concentration of the $\mathrm{Zn}$-sprayed leaves (Fig. 1), suggesting that a considerable portion of the $\mathrm{Zn}$ associated with the unwashed leaves was not phytoactive. The detergent plus acid washing caused no reduction in $\mathrm{Zn}$ concentrations of unsprayed leaves, suggesting that the procedure did not remove internal leaf $\mathrm{Zn}$.

The applied fertilizer $\mathrm{Zn}$ can be partitioned into three hypothetical classes: non-retained, loosely held surface residue, and tightly bound/ internal. Assuming that the $\mathrm{Zn} \mathrm{ni-}$ trate-sprayed leaves represent the best possible retention outcome, the difference between $\mathrm{Zn}$ concentrations 


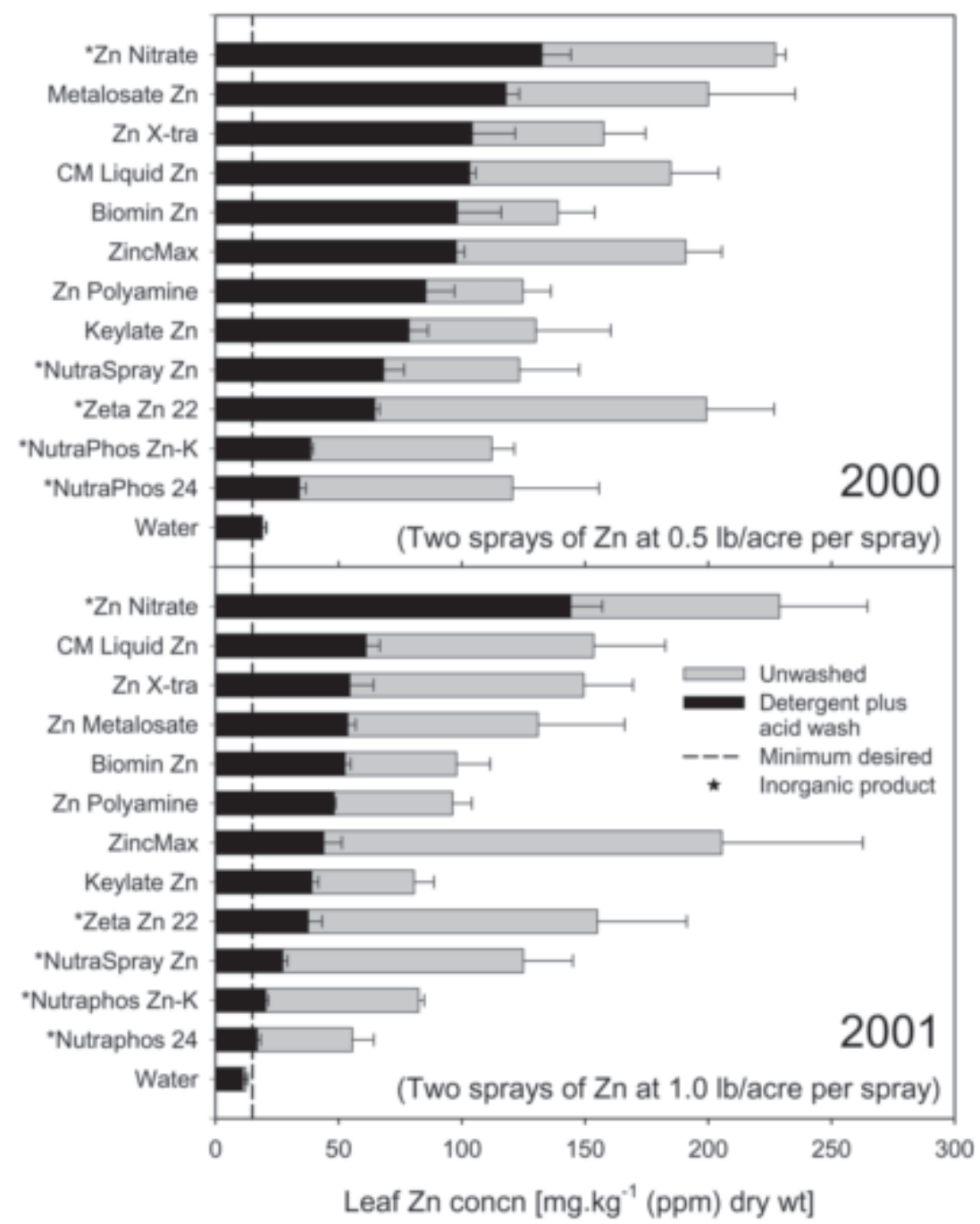

Fig. 1. Zinc $(\mathrm{Zn})$ concentration of unwashed and detergent plus acid-washed midsummer leaves of 'Golden Delicious' apple trees receiving two postbloom sprays per season of water, reagent-grade $\mathrm{Zn}$ nitrate, and 11 commercial $\mathrm{Zn}$ spray products in 2000 and 2001 . The vertical dashed line represents the minimum leaf $\mathrm{Zn}$ concentration recommended by Washington State University. The product names preceded by a star contain $\mathrm{Zn}$ as inorganic compounds; the others contain chelated or organically complexed $\mathrm{Zn}$. Each point is an average for three replicates. The error bars represent SE $\left(1 \mathrm{lb} / \mathrm{acre}=1.1209 \mathrm{~kg} \cdot \mathrm{ha}^{-1}\right)$.

of the unwashed leaves of any product and $\mathrm{Zn}$ nitrate represents applied fertilizer $\mathrm{Zn}$ that is missing at the time of leaf sampling. The missing $\mathrm{Zn}$ was presumably lost from the leaves because of poor adhesion during application or after subsequent physical weathering. Leaf $\mathrm{Zn}$ removable by detergent plus acid washing (gray portion of bars in Fig. 1) appears to represent weakly held surface residues of $\mathrm{Zn}$ derived from the applied $\mathrm{Zn}$ products. They probably have undergone some chemical transformations due to reaction with the leaf surface, rain and irrigation water, dust, other foliar sprays of pesticides and nutrients, and leaf surface-dwelling organisms. Some of the residue $\mathrm{Zn}$ likely would be available for absorption by the leaf if the $\mathrm{Zn}$ is present as or can be transformed to a soluble form when the leaf surface is wetted. Leaf $\mathrm{Zn}$ recalcitrant to detergent plus acid washing (black portion of bars in Fig. 1) includes background $\mathrm{Zn}$ derived from tree reserves and soil uptake, $\mathrm{Zn}$ absorbed by the leaf from the foliar sprays, and probably some precipitated or strongly bound $\mathrm{Zn}$ surface residues.

In the following discussion, the term "leaf $\mathrm{Zn}_{\mathrm{d}+\mathrm{a}}$ " refers to the measured leaf $\mathrm{Zn}$ concentration after the detergent plus acid washing procedure. In most cases, the $\mathrm{Zn}$ nitrate and $\mathrm{Zn}$ products that contained chelates and organic complexes produced higher leaf $\mathrm{Zn}_{\mathrm{d}+\mathrm{a}}$ than did the $\mathrm{Zn}$ products that contained inorganic forms (Table 2 ; Fig. 1). There was little difference among the chelated and organically complexed products. While Zn nitrate appears to be an effective $\mathrm{Zn}$ source for pecans (Smith and Storey, 1979), it does not appear to have ever been used commercially on apple. Zinc nitrate was not marketed as a fertilizer before the early 1970s (J.B. Storey, unpublished) and probably was not considered for apple because less expensive $\mathrm{Zn}$ products were available and effective (Luce and Bartram, 1947). The Zn phosphate-based products consistently produced the lowest mean leaf $\mathrm{Zn}_{\mathrm{d}+\mathrm{a}}$ values, reflecting the low solubility of $\mathrm{Zn}$ phosphate minerals. The Zn oxysulfate and $\mathrm{Zn}$ oxide-based products tended to demonstrate intermediate phytoavailability. These results are generally consistent with predicted $\mathrm{Zn}$ solubility based on geochemical equilibrium models (Lindsay, 1979).

There was considerable inter-year variation in leaf $\mathrm{Zn}_{\mathrm{d}+\mathrm{a}}$ (Table 2 ), and no correlation between $\mathrm{Zn}$ spray rate and leaf $\mathrm{Zn}_{\mathrm{d}+\mathrm{a}}$. These results are consistent with those reported for other $\mathrm{Zn}$-sprayed apple orchards in the Pacific Northwest (Neilsen and Hoyt, 1990). Background mineral element concentrations in apple leaves vary naturally between seasons (Bould, 1966), and additional variability is introduced by differential adherence, absorption, and loss of foliarly applied nutrients (Swietlik, 2002). All of the $\mathrm{Zn}$ spray treatments produced leaf $\mathrm{Zn}_{\mathrm{d}+\mathrm{a}}$ concentrations that fell within or above the 15 to $60 \mathrm{mg} \cdot \mathrm{kg}^{-1}$ desirable range used by Washington State University (WSU) (Tukey and Dow, 1979). Orphanos (1982) and Neilsen and Hoyt (1990) reported $\mathrm{Zn}$ toxicity symptoms of leaf burn and death associated with leaf $\mathrm{Zn}$ concentrations above 120 and 133 $\mathrm{mg} \cdot \mathrm{kg}^{-1}$, respectively. Although these values were approached and exceeded in some cases in the current experiment, no such symptoms appeared. Leaf $\mathrm{Zn}_{\mathrm{d}+\mathrm{a}}$ in the water-sprayed control treatment in 2001 and 2002, and in all experimental trees in 2003, was at or below the minimum desirable concentration of $15 \mathrm{mg} \cdot \mathrm{kg}^{-1}$. There is considerable variability in the critical value for leaf $\mathrm{Zn}$ above which $\mathrm{Zn}$ deficiency is not expected to be expressed (Bould, 1966). While the presence of deficiency symptoms and not low leaf $\mathrm{Zn}$ 
Table 2. Zinc $(\mathrm{Zn})$ concentration of detergent plus acid-washed mid-summer leaves and unwashed winter buds of 'Golden Delicious' apple trees receiving differential zinc spray treatments. The treatments are arranged in order of increasing zinc concentrations of detergent plus acid washed leaves in 2000.

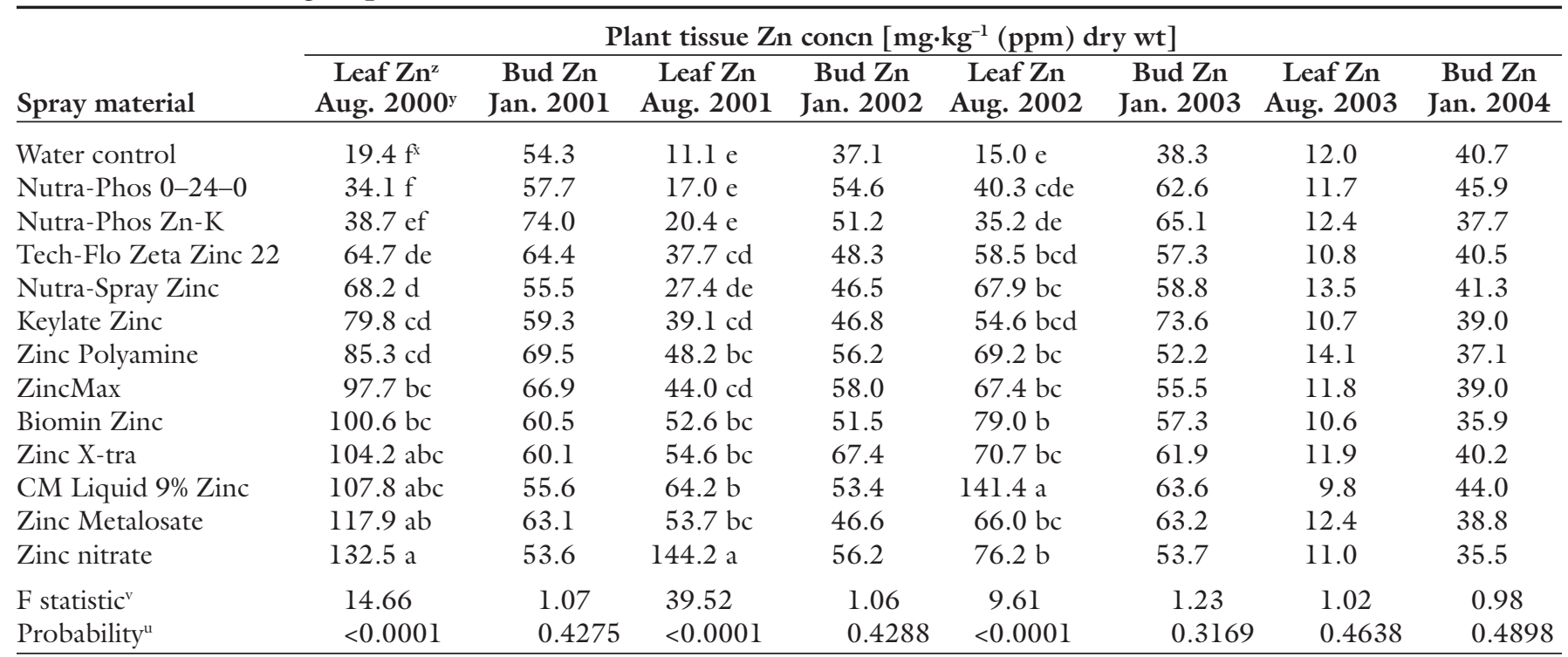

${ }^{2}$ Two sprays applied at nominal rates of $0.5 \mathrm{lb} /$ acre per spray in 2000 and $1.0 \mathrm{lb} /$ acre per spray in 2001 and 2002. No sprays were applied in $2003 ; 1 \mathrm{lb} / \mathrm{acre}=1.1209 \mathrm{~kg}$ $\mathrm{ha}^{-1}$.

yPlant tissue sampling date.

'Within-column treatment means followed by different letters are significantly different by Duncan's multiple range test $(P=0.05)$.

${ }^{v} F$-test statistic $(12,24 \mathrm{df})$

"Level of significance for F-test.

concentration appears to be the better predictor of tree Zn need (Sanchez and Righetti, 2002; Swietlik, 2002), there is a recent tendency to recommend higher minimum values to eliminate risk of inadvertent development of $\mathrm{Zn}$ insufficiency (e.g., $30 \mathrm{mg} \cdot \mathrm{kg}^{-1}$ in Agnello et al., 2005). Adoption of a higher minimum value also helps to compensate for the error introduced when using composite leaf samples (Sparks and Payne, 1982).

There was no detectable effect of the three previous seasons of $\mathrm{Zn}$ sprays on leaf $\mathrm{Zn}_{\mathrm{d}+\mathrm{a}}$ in 2003, when no $\mathrm{Zn}$ sprays were applied (Table 2 ). Similarly, there was no detectable effect in any year of the $\mathrm{Zn}$ spray treatments on bud $\mathrm{Zn}$ concentration the following winter (Table 2). While the available evidence indicates that foliarly applied $\mathrm{Zn}$ is taken up by leaves, little of the absorbed $\mathrm{Zn}$ appears to be mobilized from the leaves and redistributed to winter storage organs for remobilization the following season (Sanchez and Righetti, 2002). These results validate the current WSU recommendation for annual application of $\mathrm{Zn}$ nutritional maintenance sprays.

The Zn spray treatments had no influence on the leaf and bud concentrations of the elements other than $\mathrm{Zn}$, except for a few inconsistent significant effects attributed to statistical random- ness (data not presented). The $\mathrm{Zn}$ products containing $\mathrm{N}, \mathrm{K}, \mathrm{S}$, or $\mathrm{P}$ did not enhance leaf or bud $\mathrm{N}, \mathrm{K}, \mathrm{S}$, or $\mathrm{P}$ concentrations (data not presented). Concentrations in the detergent plus acid-washed leaves, averaged over the four years of the experiment, were (expressed in $\mathrm{g} \cdot \mathrm{kg}^{-1}$ dry weight): $\mathrm{N}$, $21 ; \mathrm{P}, 1.4 ; \mathrm{Ca}, 17 ; \mathrm{Mg}, 3.2 ; \mathrm{S}, 1.6$; and (expressed in $\mathrm{mg} \cdot \mathrm{kg}^{-1}$ dry weight): $\mathrm{Mn}, 7 \mathrm{l} ; \mathrm{Fe}, 67 ; \mathrm{Al}, 6 \mathrm{l} ; \mathrm{Na}, 45$. These values would be considered within normal ranges. Leaf $\mathrm{K}$ concentration averaged $18 \mathrm{~g} \cdot \mathrm{kg}^{-1}$ but was elevated at $21.5 \mathrm{~g} \cdot \mathrm{kg}^{-1}$ in 2002 as a result of fruit overthinning. Leaf $\mathrm{B}$ concentration directly reflected the foliar B spray program: $38 \mathrm{mg} \cdot \mathrm{kg}^{-1}$ in 2000 when B was applied in late May; 29 to $30 \mathrm{mg} \cdot \mathrm{kg}^{-1}$ in 2001 and 2002 when B was applied at delayed dormant; and $15 \mathrm{mg} \cdot \mathrm{kg}^{-1}$ in 2003 when no B was applied. Leaf $\mathrm{Cu}$ concentration was marginally low at 5 to $6 \mathrm{mg} \cdot \mathrm{kg}^{-1}$ (Agnello et al., 2005; Tukey and Dow, 1979) except in 2002, when it increased to an acceptable value of $14 \mathrm{mg} \cdot \mathrm{kg}^{-1}$ due to use of the $\mathrm{Cu}$ nutritional spray. Visual symptoms of $\mathrm{Cu}$ deficiency, such as wither-tip and chlorosis, were absent at all times.

\section{Conclusions}

The research results confirm that postbloom $\mathrm{Zn}$ sprays applied to apple trees generate substantial amounts of $\mathrm{Zn}$ residues on leaf surfaces. Detergent plus acid washing appears to remove a considerable proportion of these residues. The physical location and physiological activity of the $\mathrm{Zn}$ remaining after washing are unclear. Previous research indicates that some of the $\mathrm{Zn}$ probably is adsorbed to cuticular tissue; however, a portion of this adsorbed $\mathrm{Zn}$ appears to be available for uptake into the leaf. While leaf $\mathrm{Zn}_{\mathrm{d}+\mathrm{a}}$ likely provides a closer estimate of the "true" concentration of phytoactive $\mathrm{Zn}$ in leaves, lack of confidence in the efficiency of residue removal likely will limit its use to that of a correlative index. Applications could include comparing relative $\mathrm{Zn}$ uptake, such as is done in the current study and some of those previously cited, as well as a practical aid for diagnosing inadequate tree $\mathrm{Zn}$ status (i.e., $\mathrm{Zn}_{\mathrm{d}+\mathrm{a}}$ lower than a chosen critical value can confidently be said to indicate $\mathrm{Zn}$ insufficiency, while $\mathrm{Zn}_{\mathrm{d}+\mathrm{a}}$ higher than the critical value is uninterpretable).

Assuming that phytoactive $\mathrm{Zn}$ concentration is proportional to $\mathrm{Zn}_{\mathrm{d}+\mathrm{a}}$, the experimental results generally support commercial claims of high phytoavailability of $\mathrm{Zn}$ in chelated or organically complexed $\mathrm{Zn}$ foliar spray products. Differences among the chelated and organically complexed forms were small and inconsistent between 
seasons. Zinc in $\mathrm{Zn}$ nitrate was highly phytoavailable, whereas $\mathrm{Zn}$ in the other tested inorganic forms often but not always was less phytoavailable than in the chelated or organically complexed products. None of the $\mathrm{Zn}$ spray products applied postbloom at rates of 0.5 to $1.0 \mathrm{lb} /$ acre caused any fruit or foliage damage. All of the products were capable of increasing leaf $\mathrm{Zn}_{\mathrm{d}+\mathrm{a}}$ to values that are considered desirable. Because the inorganic $\mathrm{Zn}$-based products usually are substantially less expensive per unit of $\mathrm{Zn}$, it may be less costly and just as effective to use a higher rate of an inorganic $\mathrm{Zn}$ product as to use a lower rate of a more phytoavailable but more expensive chelated or organically complexed $\mathrm{Zn}$ product. The latter practice does confer the added benefit of reduced release of $\mathrm{Zn}$ into the environment. Failure to find evidence for a measurable increase in tree $\mathrm{Zn}$ reserves validates the current WSU recommendation for annual application of $\mathrm{Zn}$ maintenance sprays to ensure proper apple tree nutrition.

\section{Literature cited}

Agnello, A.M., A.J. Landers, D.A. Rosenberger, T.L. Robinson, J.E. Carroll, L. Cheng, P.D. Curtis, D.I. Breth, and S.A. Hoying. 2005. 2005 Pest management guidelines for commercial tree-fruit production. Cornell Univ., Ithaca, N.Y.

Ashby, D.L. 1969. Washing techniques for the removal of nutrient element deposits form the surface of apple, cherry and peach leaves. J. Amer. Soc. Hort. Sci. 94:266-268.

Benson, N.R. 1953a. Nutritional sprays for fruit trees. Proc. Washington State Hort. Assn. 49:160-165.

Benson, N.R. 1953b. Injury to fruit and foliage resulting from the spray combinations applied to apples in 1953. Proc. Washington State Hort. Assn. 49:166-172.

Boaretto, A.E., R.M. Boaretto, T. Murakoa, V.F. Nascimento Filho, C.S. Tiritan, and F.A.A. Mourão Filho. 2002. Foliar micronutrient application effects on citrus fruit yield, soil and leaf $\mathrm{Zn}$ concentrations and ${ }^{65} \mathrm{Zn}$ mobilization within the plant. Acta Hort. 594:203-207.

Bould, C. 1966. Leaf analysis of deciduous fruits, p. 651-684. In: N.F. Childers (ed.). Nutrition of fruit crops. Hort. Publ., Rutgers Univ., New Brunswick, N.J.

Chamel, A.R., R.D. Marcelle, and J.F. Eloy. 1982. Cuticular retention in vitro and localization of $\mathrm{Zn}$ after a foliar application of zinc-containing fungicides. J. Amer. Soc. Hort. Sci. 107:804-807.
Crowley, D.E., W. Smith, B. Faber, and J.A. Manthey. 1996. Zinc fertilization of avocado trees. HortScience 31:224-229.

Ferrandon, M. and A.R. Chamel. 1988. Cuticular retention, foliar absorption, and translocation of $\mathrm{Fe}, \mathrm{Mn}$, and $\mathrm{Zn}$ supplied in organic and inorganic form. J. Plant Nutr. 11:247-263.

Heeney, H.B., G.M. Ward, and W.M. Rutherford. 1964. Zinc deficiency in eastern Ontario orchards. Can. J. Plant Sci. 44:195-200.

Herrera, E. 2000. Sampling pecan leaves for analysis. Coop. Ext. Guide H-619, PH 4-102, New Mexico State Univ., Las Cruces.

Hoffman, M. and R.M. Samish. 1966. The control of zinc deficiency in apple. Israel J. Agr. Res. 16:105-114.

Labanauskas, C.K. 1966. Effects of orange leaf-washing techniques on removal of surface contaminants and nutrient losses. Proc. Amer. Soc. Hort. Sci. 89:201-205.

Labanauskas, C.K. and R.E. Puffer. 1964. Effects of foliar application of manganese, zinc, and urea on Valencia orange yield and foliage composition. Proc. Amer. Soc. Hort. Sci. 84:158-164.

Lindner, R.C. and W.A. Luce. 1944. Zinc treatment for the control of rosette or little leaf of fruit trees. Proc. Wash. State Hort. Assn. 40:154-160.

Lindsay, W.L. 1979. Chemical equilibria in soils. Wiley, New York.

Luce, W.A. and R. Bartram. 1947. The use of zinc in orchards of central Washington. Proc. Wash. State Hort. Assn. 43:101-107.

Neilsen, G.H. 1988. Seasonal variation in leaf zinc concentration of apples receiving dormant zinc. HortScience 23:130-132.

Neilsen, G.H. and E.J. Hogue. 1983. Foliar application of chelated and mineral zinc sulphate to Zn-deficient 'McIntosh' seedlings. HortScience 18:915-917.

Neilsen, G.H. and P.B. Hoyt. 1990. A comparison of methods to raise zinc concentration of apple leaves. Can. J. Plant Sci. 90:599-603.

Oberly, G.H. and D. Boynton. 1966. Apple nutrition, p. 1-50. In: N.F. Childers (ed.). Nutrition of fruit crops. Hort. Publ., Rutgers Univ., New Brunswick, N.J.

Orphanos, P.I. 1975. Spray application of zinc to young apple trees. Hort. Res. 15:23-30.

Orphanos, P.I. 1977. Removal of zinc residues from apple leaves by hydrochloric acid and leaching of other nutrients in the process. J. Sci. Food Agr. 28:643-646.

Orphanos, P.I. 1982. Spray and soil application of zinc to apples. J. Hort. Sci. 57:259-266.
Peryea, F.J. 2001. Heavy metal contamination in deciduous tree fruit orchards: Implications for mineral nutrient management. Acta Hort. 564:31-39.

Porro, D., C. Dorigatti, M. Stefanini, and A. Ceschini. 2001. Use of SPAD meter in diagnosis of nutritional status in apple and grapevine. Acta Hort. 564:243-252

Sanchez, E.E. and T.L. Righetti. 2002. Misleading zinc deficiency diagnoses in pome fruit and inappropriate use of foliar zinc sprays. Acta Hort. 594:363-368.

Smith, M.W. and J.B. Storey. 1976. The influence of washing procedures on surface removal and leaching of certain elements from pecan leaflets. HortScience 11:50-52.

Smith, M.W. and J.B. Storey. 1979. Zinc concentration of pecan leaflets and yield as influenced by zinc source and adjuvants. J. Amer. Soc. Hort. Sci. 104:474-477.

Smith, P.F., W. Reuther, and A.W. Specht. 1950. Mineral composition of chlorotic orange leaves and some observations on the relation of sample preparation technique to the interpretation of results. Plant Physiol. 25:496-506.

Smith, T.L. 2000. 2000 crop protection guide for tree fruits in Washington. Washington State Univ. Coop. Ext. Bul. EB0419, Pullman.

Sparks, D. and J.A. Payne. 1982. Zinc concentration in pecan leaflets associated with zinc deficiency symptoms. HortScience 17:670-671.

Swietlik, D. 2002. Zinc nutrition of fruit trees by foliar sprays. Acta Hort. 594:123-129.

Tukey, R.B. and A.I. Dow. 1979. Nutrient content - Fruit trees in Washington. Coop. Ext. Fertilizer Guide FG-28f, Washington State Univ., Pullman.

Washington State Legislature. 2003. Standards for apples marketed within the state of Washington: Green or yellow varieties-Washington Grade C. Washington Administrative Code Chapter 16-403-170. Washington State Legislature, Office of the Code Reviser, Olympia.

Wadsworth, G.L. 1970. Absorption and translocation of zinc in pecan trees, Carya illinoensis(Wang) K. Koch. MS Thesis, Texas A\&M Univ., College Station.

Woodbridge, C.G. 1954. Zinc deficiency in fruit trees in the Okanagan Valley of British Columbia. Can. J. Agr. Sci. 34:545-551.

Zhang, Q. and P.H. Brown. 1999a. The mechanism of foliar zinc absorption in pistachio and walnut. J. Amer. Soc. Hort. Sci. 124:312-317.

Zhang, Q. and P.H. Brown. 1999b. Distribution and transport of foliar applied zinc in pistachio. J. Amer. Soc. Hort. Sci. 124:433-436. 